Chart of Rivers Tamar and Lynher showing tidal region dealt with in this paper. Unbracketed figures $=$ Salinity (gms. of salts in 1000 gms. water). Bracketed figures $=$ State of tide at time of sampling.

$$
\begin{aligned}
& +=\text { Flow in hours. } \\
& -=\text { Ebb in hours. }
\end{aligned}
$$

H.W. $=$ High water.

L.W. $=$ Low water

Outer lines mark high water.

Inner lines mark low water.

$\ddagger=$ Upstream extent of tidal influence.
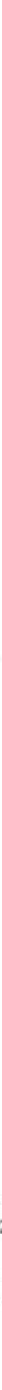

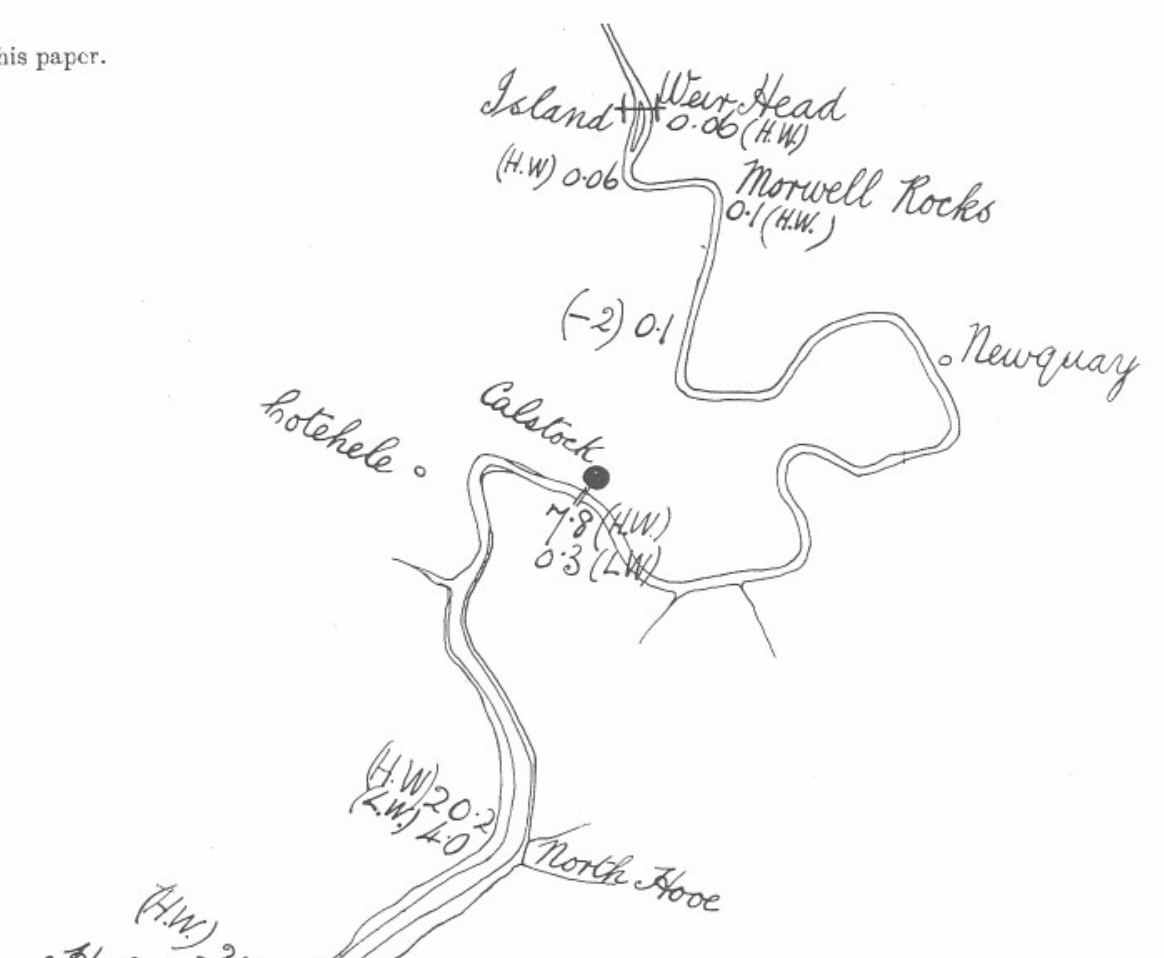

Island Herr tead

(H.W) 0.06 Morwell Rocks

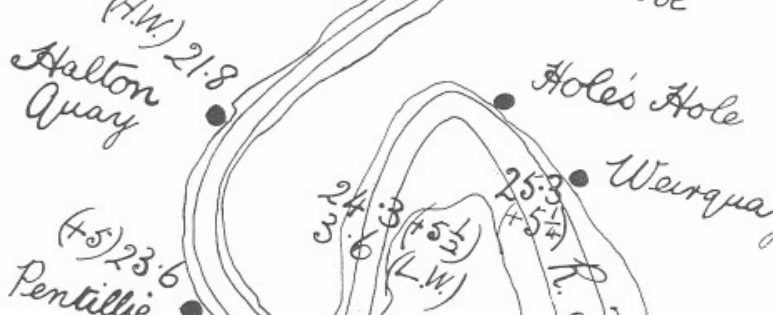

\section{encitar}

Quar

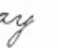

Iredinnick 

[ 81$]$

\title{
A Report on the Fauna of the Estuaries of the River Tamar and the River Lynher.
}

\author{
By \\ E. Percival, B.Sc., \\ Lecturer in Zoology, The University, Leeds. \\ Temporary Naturalist, Marine Biological Laboratory, Plymouth.
}

With 1 Figure in the Text and 1 Chart.

THE following is an account of a faunistic investigation covering those parts of the Rivers Tamar and Lynher which are affected by the tide, and was carried out during a period of six months from June to November, 1928.

\section{Description of the Area.}

The Tamar forms a portion of the boundary between Devon and Cornwall and flows in a southerly direction along a more or less winding course. (Chart.) The extent of the stream dealt with is from Plymouth Sound to Weir Head, some 19 miles inland measured along the watercourse. For about 6 miles downstream from Weir Head, the valley is rather narrow with rock exposures at different places on the convex side of bends, the water being confined to a well-defined channel with steep sides, which are uncovered by the vertical contraction of the stream at low water. The remainder of the river, down to the sea has, generally, a mudbank on each side, except at occasional bends where rock is present, which is exposed at low water by the lateral contraction due to reduction in level. The upper 4 miles of this region has narrower mud-banks than has the lower portion. These mud-banks or -flats are for the greater part more or less plane surfaces, which may slope gradually into the bed of the main channel, as happens in the lower portion of the area, or they may slope suddenly downwards at the edge, thus forming a well-marked bank to the main channel. In many cases their landward edges lie below high-water neap tide, but in others they slope imperceptibly into the adjoining land surface. In the former cases there is often a low cliff of about 2 feet bordering salt-marsh.

The constitution of the deposit has not been examined, but superficial observation shows that it is generally greyish to black mud of varying consistency, from tough clay-like material into which a man of $168 \mathrm{lbs}$. may sink to a depth of about 6 inches, to thin "slurry" into which he 
may sink to a depth of about 3 feet. The greater part of the area examined has mud into which he may sink to a depth of from 9 inches to 18 inches. The thinner mud is generally greyish, and the tougher usually black. St. John's Lake and a flat above Saltash Bridge on the left bank have a flora of Zostera, growing on a mud of medium consistency in which walking is difficult.

The banks in the upper 4 miles of the mud-flat region, where there is an abrupt slope into the main channel, are of interest on account of a change in character of the deposit along the sharp slope. The fine mud extends downwards roughly half-way, to about half-tide mark, and below there is a change to a coarse-grained material, in some cases having grains of about $1.5 \mathrm{~mm}$. diameter. Such a substratum is quite hard and clearly sandy. The reason for this is largely to be sought in the effect of the rising tide, which passes along the channel with considerable force and lifts the deposit up. The fine material is carried along upstream, and, as further rising goes on, the stream, at about half-tide, commences to spread laterally over the banks, so that a reduction in forward movement is effected with a corresponding fall in the transporting power of the current. Thus suspended material is precipitated in graded series, the fine material being laid on the broad mud-flat and the coarse on the lower part of the slope. The spreading of the water over the upper surface of a mud-flat is a gentle process, and although there is erosion it is only relatively slight, apparently a very thin layer being involved. Some time before high-water most of the lifted material is redeposited, and the turbid stream at the beginning of the tidal flow ultimately becomes relatively clear.

In the lower 9 miles or so, where the mud-flats slope gently into the main channel, this strong scouring does not appear to take place, and the water spreads gently over the banks with disturbance of little more than the merest superficial layer.

On the convex side of bends with rocky ground there is usually a thin layer of mud, which is lifted at the flow and deposited at slackening of the tide. These places are usually not densely populated, since conditions are changing too violently. If Fucus vesiculosus is present there is always a fauna, but if it is absent then the fauna is scanty.

Rocky shores are found at places in the upper 6 miles, at the large double bend above Hole's Hole to Pentillie, at Neille Point, and along the shores of the Hamoaze, below Saltash. Alongside the rock in several places the depth of water may be 20 feet to 30 feet. From the Saltash region downwards the depth is considerably more.

The portion of the River Lynher, or St. Germans River,* which is

* The Lynher, which is the longer, flows into the St. Germans River about half a mile east of St. Germans. 
dealt with, consists of a length of about 8 miles extending downwards in a roughly south-easterly direction for about 4 miles, and then approximately north-easterly for the same distance, when it joins the Tamar about $3 \frac{3}{4}$ miles from the Sound. It also shows two quite well-marked regions, the lower one being about $6 \frac{1}{2}$ miles long and the upper (St. Germans), having the characters of the upper 6 miles of the Tamar, extending about $1 \frac{1}{2}$ miles, as far as Tideford. The lower $6 \frac{1}{2}$ miles have mud-banks corresponding in character with those of the Tamar, i.e. with sharply sloping margins forming the banks of the channel, or with gently sloping surfaces, which gradually pass into the main channel.

The lower 4 miles present a fairly uniform appearance, the fall being slight, but the upper has very rapid transitional stages from the freshwater region to the brackish area, as the fall is much more marked, the whole tidal length of the St. Germans being 8 miles from Bull Point to Tideford, as compared with about 16 miles from Bull Point to Weir Head. Judging from the fauna, the 4 miles or so from Sheviock Wood to Tideford corresponds with the length of the Tamar upwards from half a mile below Pentillie Quay, a distance of about 9 miles. The same general agreement is seen in the physical nature of the two regions.

Where there are well-marked bends there are usually deposits of plant detritus on the concave side of the bend. These are known locally as "Point-stuff," and serve as sources of manure. They also play a part in the nutrition of many animals, which live on and about them. Beds of "Point-stuff" " occur more commonly in the Tamar above Hole's Hole. In the river above St. Germans, the bends are short and, although plant detritus is found, it is not nearly so extensive as in the other river.

\section{Observations on the Salinity* of the Water.}

Water samples were taken at various times and places. Owing to the circumstances which governed the work it was not possible to sample the two rivers on the same day. The tidal flow is rapid, high water at Calstock, 13 miles up, being about 23 minutes later than at Plymouth. The result of this was that samples taken at different places on the same day were not comparable, since the state of the tide was different at any two places visited. An attempt was made to obtain approximately comparable results by visiting stations at, as nearly as possible, the same state of the tide. During the present summer, when sampling was carried out, the rainfall was negligible, $3 \cdot 38$ inches being registered at Plymouth during 86 days, so that any disturbance due to excessive fresh water was eliminated. The chief disturbing factor was the variation in the size of the tide, not only from spring tide to neap tide, but in the

\footnotetext{
* Total weight of salts in grammes per 1000 gms. of sea-water.
} 


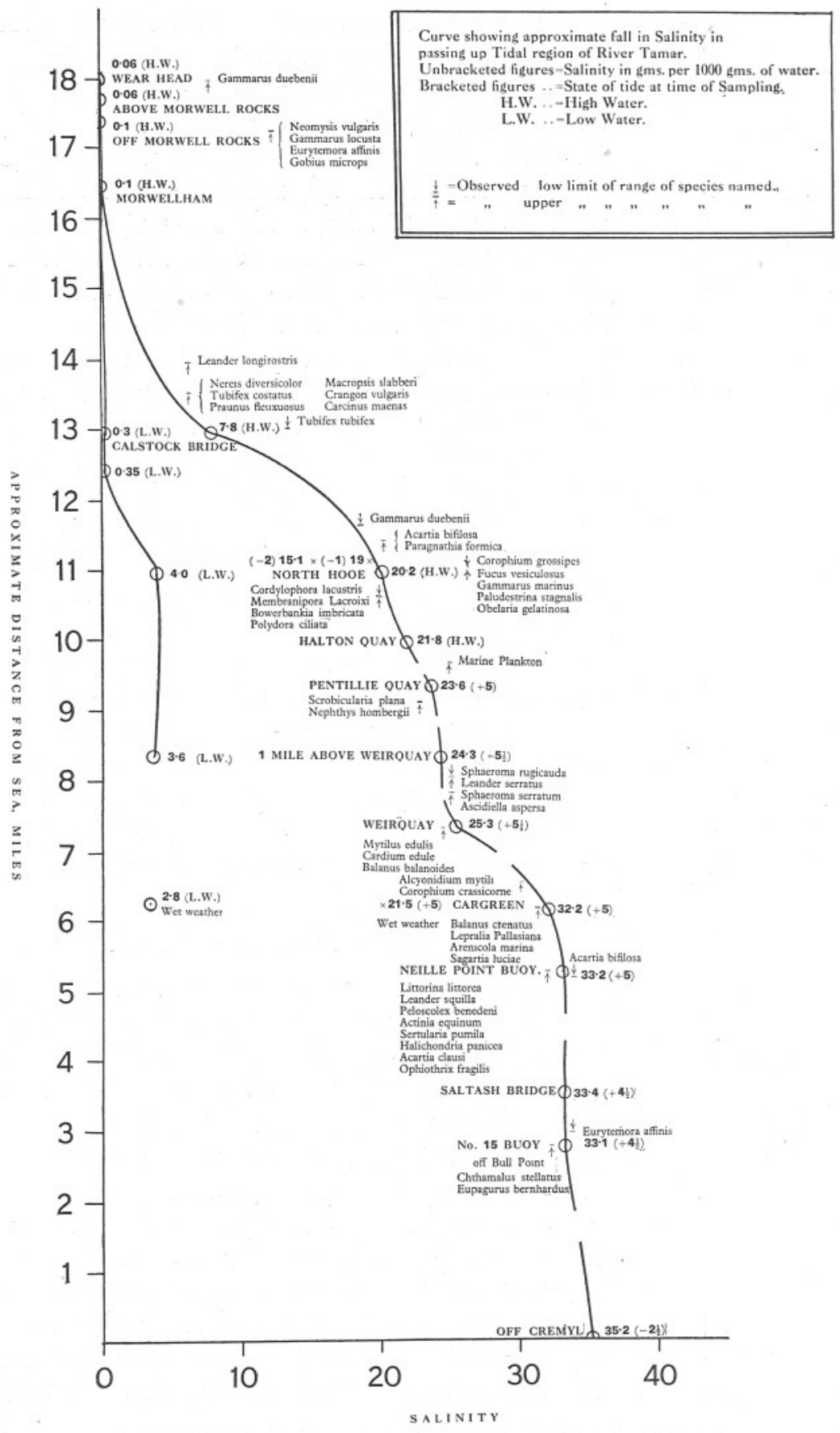

FIG. 1. 
size of the various springs and neaps, since the amount of salt water coming up was not the same at two corresponding phases of the tidal month. However, this can be neglected, as the intention was to obtain merely an approximate idea of the salinity of the stream.

The high-water salinity curve (Fig. 1) shows a gradual fall as far as Cargreen, after which there is a rapid decline to Weir Quay, about $1 \frac{1}{2}$ miles further up. From there to Pentillie, round the two bends, the fall is again gradual, while from Halton Quay it increases until there is again a marked drop between North Hooe and Calstock, a distance of about 2 miles. Above Calstock, to Weir Head where the fresh water is met, the fall per unit distance appears to decrease towards the upper limit of the tidal region. Determinations of low-water salinity indicate that the greatest variation between low- and high-water concentrations is found between North Hooe and the Weir Quay district. As will be noticed later, this is the region where a large number of marine species reach their limit of existence.

Indications of the movement of sea-water were also seen in the distribution of marine plankton. There was a rapid reduction in the variety of species in passing from the junction of the Lynher and the Tamar to the junction of the Tamar and the Tavy. From this latter region upwards there were few species, the chief being Sagitta bipunctata, Euterpina acutifrons, and Aurelia aurita, which were found to have their upper limit about half-way between Pentillie Quay and Halton Quay. Along this length, as is mentioned above, there is a marked fall in the salinity about high water. Similarly there is a reduction in the number of bottom species. It would appear that the main body of incoming sea-water does not pass Cargreen. A considerable portion goes into the Lynher and the Tavy and covers the mud-flats on each side between Saltash and Neille Point. A further large quantity is held over the flats between Neille Point and Hole's Hole.

During observations at Calstock, July 11-13, with hot dry weather, there was a scum of unicellular algæ covering the river and exposed banks at low water. This extended downwards for about three-quarters of a mile. With the incoming of the tide, this scum was pushed upstream, almost unbroken, until it lay, at high water, along a length of about $1 \frac{1}{4}$ miles immediately below Weir Head. Here the salinity was low, varying from $0.06 \%$ to about $0.3 \%$, and the mass of water was evidently largely derived from that portion which, at low water, extended down to the Cotehele locality. The place of this water would be taken by that pushed up from the lower region down to the Halton QuayPentillie Quay neighbourhood. This is suggested after a consideration of the low-water salinities at the places named. Support is added by results obtained at a point off Markwell, about 1 mile above St. Germans 
Bridge, where indications of movement of water were obtained, as follows :-

$$
\begin{aligned}
& 2 \text { p.m. salinity } 1.7^{\circ} / \mathrm{co} \\
& 2.30 \text { p.m. } \quad, \quad 1.7 \% \\
& 3.20 \text { p.m. , , } 1.9 \% \text { first indication of flow. } \\
& 3.50 \text { p.m. } \quad, \quad 2.4 \% \\
& 4.10 \text { p.m. , , } 10.7 \%
\end{aligned}
$$

Reference will be made later to these data, when the movements of organisms are considered.

The influence of wet weather on the salinity of these rivers has not been studied, but a sample at Cargreen showed a fall from $32 \cdot 2^{\circ} \%$, during dry weather, to $21.5 \%$ on a fine day but after a rainfall of $2 \cdot 14$ inches during the previous 7 days.* Both samples were taken at 5 hours of flow.

Few salinity determinations have been made in the River Lynher, but the results show that the concentration at high water, as far as Sheviock Wood, is quite high, $31.6^{\circ} \%$ at $3 \frac{1}{2}$ hours' flow. About St. Germans and Port Eliot there was a very abrupt change in salinity from low water to high water, as is indicated above, when the tide begins to flow strongly. Here the number of species is small.

The interesting shore plants, which have been noticed, are Fucus. vesiculosus, Atriplex portulacoides, and Phragmites communis. They extend to about North Hooe, Fucus and Atriplex upstream, and Phragmites downstream. The two latter meet about North Hooe, with a welldefined junction, while Fucus suddenly ceases. The seaweed is very poorly grown from Pentillie upwards, the vesicles and fronds being dwarfed.

\section{The Collection of Organisms.}

Besides the usual methods employed in shore-collecting and the use of the fine tow-net, the plankton-net devised by Russell (41) was found to be very efficient in taking the larger plankton. The net used was of stramin, and had a mouth of rectangular shape 3 feet by 9 inches. This was attached to an Agassiz frame 1 foot high, having two posterior bars 9 inches apart to which the mouth of the net was lashed. The mouth of the net was thus about $1 \frac{1}{2}$ inches from the bed of the stream when the frame was resting on the bottom. The nature of the ground rendered unnecessary the provision of a protecting outer bag. On the mud-banks and on the hard ground the apparatus worked very satisfactorily, but tended to dig up the beds of "Point-stuff." It was also used at various depths while the boat was anchored, the net being suspended against the

\footnotetext{
* Plymouth rainfall.
} 
tide. In order to sample at definite depths, an extra bridle was attached to two " eyes " at the back of the frame, and when the whole apparatus was lifted by this bridle, the frame and net hung down so that the mouth was quite efficiently closed.

Generally it was quite sufficient to make collections in this way while the boat was at rest, but when the tide slackened, at high or low water, towing was necessary.

\section{Faunistic Notes.}

Species belonging to various parts of the Animal Kingdom have been taken from the two rivers. They fall into a number of groups in so far as their distribution is concerned, viz. :-

1. Those coming in from the sea, either planktonic or benthic, which are intolerant of the changing conditions, and disappear rapidly, especially between Neille Point and Weir Quay.

2. Those coming in from the sea tolerant of considerable change in conditions, and persisting (a) to Halton Quay-North Hooe, (b) to Calstock district.

3. Brackish-water species, which replace some of the marine species. These appear between Pentillie and Hole's Hole.

4. Freshwater species tolerant of slight salinity.

By far the greatest number falls into Group 1, a very much smaller number into Group 2, Group 3 is also small, while only two, Tubifex tubifex and Sphorium casertanum, have been found in Group 4.

In considering the distribution of the various species, notice must be taken of the local variations in the conditions which determine their presence or absence. Sessile organisms requiring a solid substratum are not normally found on the mud-banks. The occurrence of odd specimens of Cereus pedunculatus attached to occasional small stones, and of Metridium senilis and Sagartia troglodytes living on small pieces of wood on mud-flats, shows forcibly the dependence of such animals upon suitable substrata. The distribution of burrowing animals is also partly dependent upon the nature of the substratum, those requiring tough mud being rarely found in very soft deposits. Generally speaking the latter type of sediment has been found to carry an exceedingly scanty macrofauna.

The channels scoured by the strong tides are poorly populated by sessile organisms, except when there is a solid bed, such as a rock exposure or a piece of masonry. Occasionally Fucus obtains a foothold in a sandy bed, and the fronds may carry Polyzoa and Hydroids, along with a number of Harpacticids. 
It is to be noticed that the fauna so far recorded consists, chiefly, of littoral species which are adapted to withstand the rapidly varying circumstances of estuarine life. The largest number of plankton species is found in the most saline region, while the brackish water has only a very few species.

\section{Protozoa.}

This part of the animal kingdom has not been studied and Polystomella crispa only has been recorded. It is very common in the more saline part of the river.

\section{Porifera.}

The sponges have been found to be limited to the water which is highly saline at high water, not extending at most beyond Cargreen. There is a great development of Halichondria panicea on the mussel-bed off Neille Point. The low-water spring-tide depth at this place was about 12-15 inches, and the bed was not observed ever to be exposed. Dr. G. P. Bidder, to whom I am indebted for its determination, describes it as of the estuarine metamp.

\section{Celenterata.}

Obelaria gelatinosa is the dominant marine cœlenterate, it being present in great quantity, especially below half-tide mark. After Hole's Hole it becomes more scanty and dwarfed, while its vertical extent becomes limited to low-water mark. Obelia geniculata has a very much more restricted range, not having been found past Weir Quay (Sal. H.W. about $25 \%,+\frac{1}{4}$ hr. $18 \cdot 8 \%$ ).

The gymnoblastic hydroids lie in two groups, Clava squamata and C. multicornis, which are the marine types disappearing past Cargreen, and Cordylophora lacustris, a brackish-water species living in the upper part of the stream, from about New Quay down to the neighbourhood of Halton Quay. The salinity range is extensive, varying, at high water, from about $0 \cdot 1 \%$ above Calstock to about $22 \%$ near Halton Quay. The densest growth is on Calstock Bridge and on the rocks at Ashburton Turn, where the vertical extent is up to half-tide. Towards the extremes of the Cordylophora region the vertical range becomes reduced to low-water mark.

The upper end of the range of Obelaria gelatinosa overlaps the lower end of that of Cordylophora.

None of the Anthozoa has been found where the high-water salinity is normally less than $33^{\circ} \%$.

Aurelia aurita breeds extensively in the asexual stage on the mussel-bed off Neille Point. The medusæ regularly invade the river during the summer months, and have been taken up as far as near Pentillie Quay. 


\section{Nemertini.}

Lineus ruber has been taken most commonly. None has been found in water having a high-water salinity of less than about $33^{\circ} \% 0^{\circ}$

\section{ANNELIDA.}

The class Polychæta provided the largest number of species in this phylum, most of them disappearing before Cargreen or when the salinity began to fall rapidly about this region. The most numerous and widely spread species found were Nereis diversicolor, Polydora ciliata, Heterocirrus zetlandicus, and Heteromastus filiformis. Arenicola marina occurs in the more saline area, and especially in the Lynher up to Ince Castle and in St. John's Lake. It soon disappears when the salinity begins to fall. The last specimens seen in the Tamar were at Cargreen. Kefersteinia cirrata and Magalia perarmata are common on the Neille Point mussel-bed, but extend very little further. The widest range is that of Nereis diversicolor, which persists into a region with a tidal variation of about $7.8^{\circ} \%$ salinity at high water to about $0 \cdot 4^{\circ} \%$ at low water. It is extremely abundant in the stiffer muds, and at all levels where the banks slope gently into the main channel. Where there is an abrupt slope into the main channel, the animal is usually absent below half-tide mark, the deposit here being sandy. Above half-tide mark the sediment rapidly becomes fine, so as to produce a substratum in which the worm can easily burrow.

Polydora ciliata has been found as far up as a region having a tidal salinity variation of from about $20 \%$ to $4 \%$. Although, in the Saltash district, it has been taken chiefly from its normal habitat, shells, in other places it has been found living in mud, and very commonly in mud tubes constructed in narrow cracks in rock. During the summer the plankton, from as far up as North Hooe, was found to contain large numbers of the larvæ of Polydora.

Of the Oligochæta, Tubifex costatus and Clitellio arenarius have a range similar to that of Nereis diversicolor. They are both abundant in the stiffer mud and beneath stones in muddy places. Peloscolex benedeni is associated with them until the salinity begins rapidly to fall. Tubifex tubifex extends from the fresh water into the upper brackish region. It may be regarded as succeeding $T$. costatus.

\section{Crustacea.}

The Cladocera are recorded only from the highly saline area.

Of the Copepoda Gymnoplea the species of greatest interest are Acartia Clausi, A. bifilosa, and Eurytemora affinis. A. Clausi is abundant in the 
Hamoaze, diminishing in numbers above Saltash and finally disappearing about the confluence of the Tamar and the Tavy. A. bifilosa makes its appearance about this point, becomes numerous about Hole's Hole, and disappears somewhere near the Cotehele district. It has not been seen in the plankton from Calstock. Eurytemora affinis is scarce in the Saltash area, increases by Hole's Hole, forms the greater part of the plankton upwards along the river, until at Calstock it is present as almost a pure culture. Shortly after this point the numbers fall off rapidly, disappearance taking place near Morwell Rocks.

The salinity range at high water for $E$. affinis was determined to be approximately $33 \%$ to $0.1 \%$.

The brackish-water Gymnoplea were found to be much more numerous at the beginning of November than at any other time during the summer, there being indications of an autumn-winter maximum. The adult females were all carrying eggs, and an enormous number of larvæ and young adults were found. It is noteworthy that, in a series of collections made between Neille Point and Morwell Rocks (7.11.28), the samples from the upper part of the river contained only adults with all the females carrying eggs, while those from the lower portion contained many larvæ and young adults, and relatively fewer egg-bearing females.

The Harpacticidæ are mostly littoral species, and do not appear to extend beyond a lower salinity limit of about $20 \%$ at high water. The weed on the buoys in the Hamoaze and off Neille Point carries a very dense fauna, consisting chiefly of Idya furcata, Thalestris longimana, and Parathalestris Clausi. Notodelphys Allmani is coextensive with its host Ascidiella aspersa, which is restricted to the region of high salinity.

The distribution of the four species of Cirripedia Thoracica shows Chthamalus stellatus to have the narrowest range, Balanus balanoides and $B$. crenatus extending further up, but being restricted to a lower salinity limit of about $33^{\circ} \%$, and B. improvisus occurring furthest up in the region of great salinity variation, between low and high water.

In the up-river localities there were indications that additions to the barnacle population were made very occasionally since, at Cargreen, above Halton Quay and at St. Germans Bridge, there were no examples seen which could be regarded as having been deposited this year. All the specimens were very large, and apparently aged. During the summer, large numbers of Balanus nauplii from 5-12\% of the total catch, were taken in the region of the mouth of the River Lynher, but none was seen in collections made off Neille Point.

Sacculina carcini has a limited distribution. No specimens of infected Carcinus manas were taken above Neille Point. The nauplii were very abundant in plankton taken in the Hamoaze, but none appeared to get up to the Neille Point district. 
The Schizopoda contributed four species, of which Schistomysis ornata had the shortest range and the least significance from the point of view of number. The most abundant Mysid was Neomysis vulgaris, Macropsis slabberi was somewhat less, on the whole, and Praunus flexuosus much less than either. Neomysis and Praunus were usually found at or near the bottom, feeding on detritus. Of the mobile organisms the Mysids may be regarded as of the utmost importance in the conversion of detritus into animal matter. This importance, in the estuaries, can hardly be exaggerated.

Macropsis is usually found swimming freely in the more open water, and may be considered as a pelagic animal. Collections at different depths showed generally that it was most abundant in the upper portion of its vertical range, and was only occasionally taken within 1 foot of the bottom. On the other hand, Praunus and Neomysis were almost always thick within 1 foot of the bottom, and either absent or very poorly represented higher up. In shallow water, of about 1 fathom or less, the three species would be found well mixed down to the bottom. Occasionally, as when much fresh water was coming down, Neomysis and Praunus were taken near the surface. At such times there was a fair amount of turbidity.

The Mysids in the estuaries are moved about very much by the tide. Observations above St. Germans, near Markwell, gave the following data, collections being made with the stramin net resting on the bed, 10-minute hauls, in a stream, at most, 1 foot deep, the net being placed mouth upstream :-

\begin{tabular}{|c|c|c|c|c|}
\hline & & $\begin{array}{l}1.30 \text { p.m., } \\
\text { a few minutes } \\
\text { before L.W. }\end{array}$ & $\begin{array}{c}2.40 \text { p.m., } \\
\text { during } \\
\text { L.W. period. }\end{array}$ & $\begin{array}{c}3.25 \text { p.m. } \\
\text { after } \\
10 \text { mins. flow. }\end{array}$ \\
\hline Neomysis vulgaris & . & . 40 & 10 & 6970 \\
\hline Crangon vulgaris . & $\cdot$ & . 11 & 一 & 4 \\
\hline Gammarus locusta & . & & 1 & 1 \\
\hline
\end{tabular}

Reference to the notes on salinity changes at this place (p. 86) will show that the rise in salinity commenced after 3.20 p.m., and was very marked at 4.10 p.m. As the water moved upstream the swarms of Mysids could be seen, in the shallow water along the edge, to form a thick soup, and the water surface here was bespattered with splashes, caused by the jumping of the myriads of overcrowded animals. This phenomenon was observed regularly, at the turn of the tide and for some time afterwards, until they were more thinly distributed over the substratum. A similar concentration takes place along the edge of the tide, as it ebbs from the mud-banks.

It is noticeable that the Mysid fauna at the edge of the tide is, in effect, a Neomysis fauna. The vertical distribution of Neomysis and Macropsis, 
in the deeper parts, may be fairly generally expressed by the following table :-

\begin{tabular}{|c|c|c|c|c|c|}
\hline $\begin{array}{l}\text { Off Sheviock Wood } \\
\text { R. Lynher. }\end{array}$ & $\begin{array}{l}2 \mathrm{ft} \text {. deep. } \\
\% \text { of } \\
\text { total. }\end{array}$ & $\begin{array}{l}7 \mathrm{ft} \text {. deep. } \\
\% \text { of } \\
\text { total. }\end{array}$ & $\begin{array}{l}13 \mathrm{ft} \text {. deep. } \\
\% \text { of } \\
\text { total. }\end{array}$ & $\begin{array}{l}20 \mathrm{ft} \text {. deep. } \\
\% \text { of } \\
\text { total. }\end{array}$ & $\begin{array}{l}\text { Bottom } 24 \mathrm{ft} \\
\quad \% \text { of } \\
\text { total. }\end{array}$ \\
\hline Macropsis slabberi & $98 \cdot 5$ & 29 & 67 & 64 & - \\
\hline Neomysis vulgaris & - & $8 \cdot 4$ & 18 & $14 \cdot 2$ & 47 \\
\hline Praunus flexuosus & - & 43 & 4 & - & 一 \\
\hline Crangon vulgaris & 一 & - & - & - & 27 \\
\hline
\end{tabular}

The table does not show the usual distribution of Praunus, but in all other collections, whether singly from the bottom or in vertical series, this animal has been taken chiefly within the lowest foot or so of the bed. It and Neomysis are to be taken in great numbers among Fucus.

The three species are capable of suffering a very wide range of salinity changes; especially is this the case with Neomysis, which extends from the sea up to Morwell Rocks, with a high-water salinity of about $0.1^{\circ} \%$. The other two do not persist far beyond Calstock, where the high-water salinity was $7 \cdot 8^{\circ} \%$ and low-water $0.3^{\circ} \%$.

Neomysis was observed breeding throughout the summer and into November, while Praunus and Macropsis were not taken with full broodpouches later than the beginning of September.

Three species of Isopoda claimed special attention, viz. : Spharoma serratum, S. rugicauda, and Paragnathia formica. The first is a marine species, which extends up the Tamar to about half-way between Hole's Hole and Pentillie Quay, where the high-water salinity was 24\% ; S. rugicauda succeeded it and persisted to a region a little above Calstock. The same succession was observed in the Lynher, the junction of the two ranges being near Sheviock Wood. S. rugicauda was found almost at the upper limit of the tidal zone, near Tideford. This species provided examples having one to three notches on the postero-lateral border of the exopodite of the uropod, collected at Calstock and St. Germans.

Paragnathia formica was also common in both rivers. In the Tamar, the determined range was from Neille Point to a piece of hard ground opposite the hamlet of Boheterick, a little distance below Calstock, with a high-water salinity of well below $20^{\circ} \%_{0}$. It was collected from the edge of salt marshes near high-water mark, in circumstances such as were described by Omer-Cooper (36), and from beneath stones at about halftide. The praniza stage was often taken in the stramin net at various depths.

The Amphipoda have presented interesting examples of species range and succession.

Three species of Gammarus have been taken commonly, G. marinus, G. locusta, G. duebenii. The first was found to be co-extensive with Fucus 
vesiculosus, and was not found further up than North Hooe. G. locusta was found to be very common and extended up to Morwell Rocks. $G$. duebenii was met with first opposite Cotehele Woods, below Calstock, and was common up to Weir Head, where the water was apparently fresh (H.W. Sal. 0.06\% $\%_{\circ}$ ). It was abundant in the moss Eurhynchium rusciforme.

G. marinus was usually found among Fucus and under stones, $G$. locusta was also taken swimming freely, chiefly near the bottom, and was very abundant, in company with Neomysis and Praunus, on the banks of vegetable debris ("Point-stuff"), which formed at bends. $G$. duebenni was taken in similar circumstances to those of $G$. locusta, and may be regarded as succeeding the latter in brackish water.

Corophium crassicorne extends from the sea to about half-way between Cargreen and Weir Quay, where the salinity undergoes a considerable fall. It is very abundant among the weed growing on buoys in the Hamoaze and further upstream, and along the shore. Corophium grossipes succeeds it in the upper part of the stream, it having been met with first near North Hooe. This species burrows in the earthen banks and in the stiffer mud, and forms U-shaped earthen tunnels under stones. In the Calstock district it is very abundant and replaces Nereis diversicolor in the banks. A similar relation between the worm and the amphipod was seen in the River Tiddy, between St. Germans and Tideford. The upper limit was not discovered in the Tamar, but in the Tiddy it was coincident with the end of the tidal zone.

Seven species of Decapoda were recorded of which six may be considered. The genus Leander provided three species, viz., L. serratus, which extends almost up to Pentillie Quay, it being most abundant in the region of higher salinity, and is commercially exploited about Saltash and the lower district; L. squilla, which was not taken above Neille Point, but probably extends somewhat further, since it was common at this place; and L. longirostris, which occurs frequently in the Lynher and Tiddy, and in the Tamar above Hole's Hole, extending as far as about a mile above Calstock. A few juvenile specimens of this last species were taken in St. John's Lake. Gurney (18) records the taking of young stages of this species off Plymouth. L. serratus and I. squilla are also common in the Lynher.

Palcmonetes varians has been found abundantly about St. Germans, both in pools on the salt marsh, and in the side streams communicating with the river. It was taken also in the Tamar, a little above Calstock. On the whole, this species is much less abundant in the main stream than in the small lateral diverticula. It thrives well in a salinity change of from less than $0 \cdot 3^{\circ} \%$ to $29 \cdot 6^{\circ} \%$.

Crangon vulgaris and Carcinus manas have a range about the same 
as that of Nereis diversicolor, and are both common. In the upper portion of the Tamar, about Calstock, they appear to be smaller than nearer the sea. Large numbers have been taken from the beds of "Pointstuft," in company with Neomysis, Praunus, and Gammarus locustr.

\section{Mollusca.}

The common molluscs are few in species. In spite of the fact that there is a considerable amount of rock exposed within the observed range of Patella vulgata, this species has been found only rarely. Littorina littorea and L. obtusata are both common as far as Sheviock Wood and Neille Point, on both hard and soft ground. Old dead shells of L. obtusata were picked up beside Cargreen, but no signs of living examples were seen. The egg-capsules of L. littorea were taken in the plankton, half a mile above St. Germans Bridge. Paludestrina stagnalis was found swarming over the mud-flats which carry Zostera, viz.: St. Germans Lake and the flat next above Saltash Bridge, on the left bank. Its numbers diminish rapidly past Cargreen and it is found only occasionally above Pentillie. Mytilus edulis and Cardium edule have a commercial value about Saltash, many being collected up as far as Warren Point on the left bank, and Neille Point on the right. The mussel-bed off the latter point is quite extensive, lying in water from 12 inches to 18 inches at low tide. Ostrea edulis has been taken from the mussel-bed, and is said to be abundant in the vicinity. Scrobicularia plana is the only other molluse which has been taken commonly. It is found in the stiff mud of St. John's Lake, of the Lynher as far as Port Eliot, and in the Tamar as far as Pentillie. It tends to decrease in number as the mud becomes softer or more sandy, and also as it is followed into the less saline waters.

\section{PolyzoA.}

Membranipora Lacroixii and Bowerbankia imbricata were taken up as far as half a mile above Halton Quay, where the salinity range from high to low water was approximately $21 \%$ to $4 \%$. The latter species is exceedingly abundant as far up as Cargreen, covering the Fucus fronds, in some cases, almost completely. Membranipora is also common, especially on stones and shells. Lepralia Pallasiana and Alcyonidium mytili both cease a little way beyond Cargreen, where the high-water salinity begins rapidly to decrease. They also are very abundant.

\section{Tunicata.}

Oikopleura dioica moves with the tide and does not appear to pass Saltash. Ascidiella aspersa is the common species, it being very abundant 
on the mussel-bed off Neille Point, and becoming rapidly scarcer until it ends about Hole's Hole in the Tamar, and about Sheviock Wood in the Lynher.

\section{Pisces.}

For the purpose of these notes only Gobius microps will be considered here. It is present in great quantity and ranges up to Morwell Rocks. At Calstock it formed in three samples, taken with the stramin net, $10 \cdot 4 \%, 15 \%$, and $25 \%$ respectively of the total (29.6.28). Large numbers are to be found, at low water, in the small channels traversing mud-banks, and in pools. Along the edge of the tide, immediately after the Mysids have passed, they may be taken in abundance. When the mud-flats are covered by the tide, Gobius spreads out over the bed similarly to Neomysis and Praunus, but not in such quantity. It feeds chiefly upon Mysids and Copepods, and is to be regarded as a serious competitor of the young Clupeoids which live in the estuaries (15).

I wish to record my indebtedness to Dr. E. J. Allen, F.R.S., and the staff of the Marine Biological Laboratory, Plymouth, for valuable assistance and continued interest, to Dr. G. P. Bidder, Miss S. L. Garstang (Mrs. A. C. Hardy), Mr. W. Edgar Evans, Mr. R. Gurney, and Professor W. M. Tattersall, who have decided certain species for me, and to the Council of the University of Leeds who gave me leave of absence to carry out the investigation.

\section{Note on Heterocirrus zetlandicus.}

The worm which is recorded here under this name, although answering in most of its characteristics to the description of the species, differs from the type in not possessing crochets. All the setæ are capillary bristles, but in cases where they are broken the stumps have a resemblance to those figures of crochets given in Southern, Clare Island Survey, Proc. Roy. Irish Acad., XXXI-2, 1914, Pl. XII, Fig. 29 J.K. It agrees closely with stage B, loc. cit., pp. 47, 117, 118, and the possibility suggests itself that the crochets described and figured by Southern were broken capillary bristles, damaged either recently or at a more remote period.

\section{FAUnistic List (Compare with lists in 1, 2, 3, 37, 38).*}

\section{PROTOZOA FORAMINIFERA :}

Polystomellinæ

Polystomella crispa L. (53). Common in Tamar; taken up to $\frac{1}{2}$ mile above Cargreen. Common among tow-nettings and-dredgings.

* Figures in thick type refer to the list of References on p. 107. 
METAZOA Porifera :

Haploscleridæ.

Halichondria panicea Pallas (6). Rat Island and Hamoaze; massive growth on Neille Point mussel-bed.

Axinellidæ.

Hymeniacidon sanguineum Grant (6). Rat Island; Weir Point.

Gymnoblastea.

Clavidæ.

Clava multicornis Forskål (4). Occasional, on wood and stones in main channel off Cargreen.

Clava squamata O.F.M. (4). Relatively common in main channel off Cargreen.

Cordylophora lacustris Allman (4). Abundant above, at, and below Calstock; massive growth on Calstock Bridge, and on rocks below Cotehele Woods. Extends down to within $\frac{1}{2}$ mile of Halton Quay.

Calyptoblastea.

Campanulariidæ.

Obelia geniculata L. (22). On Fucus, as far as Cargreen in Tamar, and hard ground, by boathouse near Ince Castle in Lynher.

Obelaria gelatinosa Pallas (22). Abundant in Tamar, extending to North Hooe; abundant in Lynher, extending to Port Eliot.

Gonothyraea Lovéni Allman (22). On Fucus near Warren Point, R. Tamar ; on Fucus near boathouse by Ince Castle, R. Lynher.

Sertulariidæ.

Sertularia pumila L. (22). On Fucus up to Neille Point, and to boathouse by Ince Castle.

Eucopidæ.

Phialidium hemisphaericum Gronovius (29). Taken in plankton up to within 1 mile of Pentillie Quay, R. Tamar, and up to Sheviock Woods, R. Lynher. Very abundant in Hamoaze and adjacent waters during summer.

Discomeduse.

Ulmaridæ.

Aurelia aurita Lamarck (29). Medusæ taken to within 1 mile of Pentillie Quay, R. Tamar; Scyphistomæ abundant on Neille Point mussel-bed, also at Cargreen Hard, and above Antony Creek, R. Lynher. 
ZOANTHARIA.

Actiniidæ.

Actinia equina L. (17). On Rocks up to Neille Point, R. Tamar ; up to boathouse near Ince Castle, R. Lynher.

Metridium senilis L. var. pallidum (17). On piece of wood $\frac{1}{2}$ mile above Saltash Bridge.

Sagartia lucice Verrill (30). On rocks at Bull Point, Hamoaze ; Neille Point and Cargreen Hard, R. Tamar.

Sagartia troglodytes Gosse var. ornata (17). On piece of wood, $\frac{1}{2}$ mile above Saltash Bridge; mussel-bed off Neille Point, R. Tamar.

Cereus pedunculatus Pennant (17). Rat Island; St. John's Lake.

Diadumene cincta T. A. Steph. (51). Mussel-bed off Neille Point, R. Tamar.

Nemertini.

Amphiporidæ.

Amphiporus lactifloreus Johnston (25). Under stones, between Saltash Bridge and Warren Point.

Tetrastemmidæ.

Prostoma melanocephalum melanocephalum Johnston (8). Under stones, between Saltash Bridge and Warren Point; Rat Island.

Lineus bilineatus Renier (8). Mussel-bed off Neille Point.

\section{ROTIFERA.}

Synchata gyrina Hood (34). Common in plankton between Neille Point and Cotehele (Nov.).

Polycheta.

Syllidæ.

Syllis gracilis Grube (12). Rat Island.

Syllis prolifera Krohn (12). Bull Point, Hamoaze; mussel-bed off Neille Point.

Odontosyllis ctenostoma Claparède (12). Mussel-bed off Neille Point.

Exogone gemmifera Pagenstecher (12). Shore, by boathouse near Ince Castle, R. Lynher.

Autolytus prolifer O.F.M. (12). In plankton from Hamoaze, off Bull Point.

Hesionidæ.

Kefersteinia cirrata Keferstein (12). Rat Island; common in musselbed off Neille Point.

Magalia perarmata Marion and Bobretsky (12). Common on musselbed off Neille Point; Cargreen Hard.

NEW SERIES.-VOL. XVI. No. 1. MAY, 1929. 
Aphroditidæ.

Lagisca extenuata Grube (12). Mussel-bed off Neille Point.

Harmothoê impar Johnston (12). Mussel-bed off Neille Point.

Pholoë minuta Fabr. (12). Cargreen Hard.

Phyllodocidæ.

Phyllodoce maculata L. (12). Rat Island.

Nereidæ.

Leptonereis glauca Clap. (12). Mussel-bed off Neille Point.

Nereis (Perinereis) cultifera Grube (12). Rat Island.

Nereis (Hediste) diversicolor O.F.M. (12). Dominant animal in mudbanks, extending to $\frac{1}{2}$ mile above Calstock, and to about 1 mile below Tideford.

Nephthydæ.

Nephthys Hombergii Lamarck (12). Widely distributed in mud, up to Pentillie Quay, and to lower end of Sheviock Wood.

Glyceridæ.

Glycera alba Rathke (12). Rat Island, in mud.

Spionidæ.

Scolecolepis fuliginosa Clap. (13). Neille Point, in small pool.

Nerine foliosa Aud. et M-Ed. (13). Rat Island, in mud.

Pygospio elegans Clap. (13). Shore, by boathouse near Ince Castle.

Polydora ciliata Johnston (13). Widely distributed up to $\frac{1}{2}$ mile beyond

Halton Quay and to Port Eliot. In mud, in clefts in rock, and in shells of Ostrea and Balanus.

Polydora hoplura Clap. (13). Mussel-bed, Neille Point.

Cirratulidæ.

Audounia tentaculata Montagu (13). St. John's Lake; Rat Island.

Cirratulus cirratus O.F.M. (13). Rat Island; shore, by boathouse near Ince Castle.

Heterocirrus zetlandicus McIntosh (13). Common in stiff mud, up to Neille Point; Rat Island.

Streblospio Shrubsolii Buchanan (13). Occasional, in mud off Port Eliot, and up to $\frac{1}{2}$ mile above Halton Quay.

Terebellidæ.

Lanice conchilega Pallas (13). St. John's Lake ; Rat Island ; shore, by boathouse near Ince Castle.

Ampharetidæ.

Ampharete Grubei Malmgren (13). St. John's Lake.

Melinna palmata (13). Wivelscombe Lake; Rat Island. 
Capitellidæ.

Heteromastus filiformis Clap. (13). Common in stiff mud, in R. Tamar up to Neille Point, and in R. Lynher up to Sheviock Wood.

Capitella capitata Fabr. (13). Rat Island; shore, by boathouse near Ince Castle.

Arenicolidæ.

Arenicola marina L. (13). Up to Cargreen, and to confluence of R. Lynher and R. Tiddy.

Sabellidæ.

Dasychone bombyx Dalyell (13). St. John's Lake.

Serpulidæ.

Pomatoceros triqueter L. (13). Up to Hole's Hole, and to Sheviock Wood. Commoner nearer the sea.

Spirorbis spirillum L. (13). Off Neille Point on stones.

Spirorbis borealis Daudin (13). Rat Island on Fucus and stones.

OLIGOCH ATA.

Naididæ.

Chatogaster diaphanus Gruith (31). Among moss at Weir Head; a freshwater species in company with brackish-water forms.

Nais elinguis Müller, Oerstedt. (31). In moss with Chætogaster.

Tubificidæ.

Tubifex costatus Clap. (32). Widely distributed and common in mud, and under stones on mud and muddy sand, up to $\frac{1}{2}$ mile beyond Calstock Bridge, and to mud-flats above St. Germans Bridge.

Tubifex tubifex Müller (31). Extending from fresh water down to about $\frac{1}{3}$ mile above Calstock. In R. Tiddy near Tideford.

Clitellio arenarius Müller (32). In stiff mud and muddy sand, and under stones, up to $\frac{1}{2}$ mile above Calstock Bridge, and to shore, by boathouse near Ince Castle.

Peloscolex Benedeni Udeken (32). Up to Neille Point and Port Eliot, in stiff mud and muddy sand. Common.

Chætognatha.

Sagitta bipunctata Quoy and Gaimard (19). R. Tamar. Occasional specimens in plankton, $\frac{1}{2}$ mile beyond Pentillie Quay.

BRANCHIOPODA.

Podon intermedius Lilljeb. (34). In Plankton, up to Neille Point, and to Sheviock Wood.

Evadne Nordmanni Lovén (34). In plankton, off Impregnable. 
Chydorus sphaericus O.F.M. (26). Near lower end of Weir Island, Weir Head, in water carrying brackish-water forms. A freshwater species.

\section{Copepoda.}

Calanidæ.

Calanus finmarchicus Gunnerus (44). At mouth of Hamoaze.

Pseudocalanidæ.

Pseudocalanus elongatus Bœck (44). In plankton off Impregnable.

Centropagidæ.

Centropages typicus Kröyer (44). Up to mouth of R. Tavy.

Temoridæ.

Temora longicornis O.F.M. (44). Up to mouth of R. Tavy.

Eurytemora affinis Poppe (16). From about Impregnable to Morwellham Quay and to Port Eliot. Common in brackish water.

Eurytemora velox Lilljeb. (16). In shallow pool on salt marsh above St. Germans.

Parapontellidæ.

Parapontella brevicornis Lubbock (44). In Hamoaze off Impregnable.

Acartiidæ.

Acartia Clausi Giesbr. (44). Common in Lynher, and in Tamar up to Neille Point.

Acartia bifiosa Giesbr. (16). Common in Tamar from Neille Point to near Cotehele.

Cyclopidæ.

Oithona helgolandica Claus (46). Up to Neille Point and to Antony Passage. Common.

Cyclopina longicornis Bœck (46). Up to Saltash. Common.

Harpacticoida.

Longipedia minor Scott (45). Neille Point; Hole's Hole, amongst weed and on mud.

Ectinosoma melaniceps Bœck (47). Cargreen Hard.

Euterpina acutifrons Dana (45). In plankton, to Halton Quay.

Harpacticus chelifer Müller (45). In weed, on Neille Point buoy.

Harpacticus gracilis Claus (45). Up to Halton Quay and to Sheviock Wood, in plankton and on bottom. Common.

Harpacticus flexus Brady (45). Up to Hole's Hole. Common.

Alteutha interrupta Goodsir (45). On Neille Point buoy, and in townettings from off Wivelscombe Lake. 
Idya furcata Baird (45). Common on buoys and on shore, also in townettings. Up to Hole's Hole, and boathouse by Ince Castle.

Thalestris longimana Claus (45). Up to Neille Point buoy. Common on buoys.

Parathalestris harpacticoides Claus (45). On No. 15 Buoy, Hamoaze.

Parathalestris Clausi Norman (45). On buoys up to Neille Point. Common.

Dactylopusia thisboides Claus (45). Rat Island; up to Neille Point buoy.

Dactylopusia vulgaris G. O. Sars (45). Neille Point, in pool at half-tide. Dactylopodella flava Claus (45). Rat Island.

Laophonte proxima G. O. Sars (45). Cargreen Hard; Hole's Hole. On Bowerbankia.

Laoplionte simitis Claus (45). On shore, by boathouse near Ince Castle.

Laophonte Strömi Baird (45). Common on buoys up to Neille Point.

Laophonte abbreviata G. O. Sars (47). Half a mile above Cargreen, on mud.

Enhydrosoma propinquum Brady (45). In tow-nettings, off Impregnable and near Sheviock Wood.

Cymbasoma longispinosum Bourne (48). In tow-nettings, up to Sheviock Wood, and to Neille Point buoy.

Corycæidæ.

Corycaus anglicus Lubbock (y). In plankton, oft Impregnable.

Notodelphydæ.

Notodelphys Allmani Thorell (48). In Ascidiella aspersa, up to Hole's Hole, and Sheviock Wood.

Ascidicola rosea Thorell (48). In Ascidiella aspersa, Sheviock Wood.

\section{Cirripedia.}

Balanidæ.

Balanus balanoides L. (10). Up to shore by boathouse near Ince Castle, and to Cargreen. Common.

Balanus crenatus Bruguière (10). Up to shore by boathouse near Ince Castle, and to Cargreen. Fairly common.

Balanus improvisus Darwin (10). Half a mile above Halton Quay; St. Germans Bridge.

Chthamalus stellatus Poli (10). Bull Point, Hamoaze.

Peltrogastridæ.

Sacculina carcini Thompson (52). On Carcinus manas up to Neille Point. 
SchIZOPODA.

Mysinæ.

Praunus flexuosus Müller (34). Common up to $\frac{1}{4}$ mile above Calstock, and to $\frac{1}{2}$ mile above St. Germans Bridge.

Schistomysis ornata G. O. Sars (34). Up to Sheviock Wood.

Macropsis Slabberi v. Beneden (34). Abundant. Up to $\frac{1}{2}$ mile above Calstock, and 2 miles above St. Germans.

Neomysis vulgaris Thompson (34). Very abundant. Up to Morwell Rocks, and to Penimble, R. Tiddy.

ISOPODA.

Anthuridæ.

Anthura gracilis Montagu (35). Occasional. Rat Island; off Port Eliot. In mud.

Spharoma serratum Fabr. (49). Up to 1 mile above Weir Quay, and to Wivelscombe Lake.

Spharoma rugicauda Leach (49). From $\frac{1}{2}$ mile below Pentillie Quay to $\frac{1}{2}$ mile above Calstock; from Sheviock Wood to Tideford. Abundant.

Dynamene rubra Leach (49). Shore at Bull Point, Hamoaze.

Limnoriidæ.

Limnoria lignorum Rathke (43). In log, on mud-flat $\frac{1}{2}$ mile above Cargreen.

Gnathiidæ.

Paragnathia formica Hesse (33). Neille Point to 1 mile below Calstock ; about junction of R. Lynher and R. Tiddy and main stream. Common. Got from edge of salt marsh about H.W., and in tow-nets.

Janiridæ.

Jara marina Fabr. (43). Common at Bull Point, Hamoaze; shore, by boathouse near Ince Castle.

Idotheidæ.

Idothea baltica Pallas (43). St. John's Lake among Zostera; off Ince Castle.

Ligiidæ.

Ligia oceanica L. (43). In rocks by Ince Castle; in wall above Saltash Bridge.

Cryptoniscinæ.

Hemioniscus balani Spence Bate (52). In Balanus balanoides from St. John's Lake and Bull Point. 


\section{AMPHIPODA.}

Hyperiidæ.

Hyperia galba Mont. (42). One mile below Pentillie Quay, Aurelia aurita also taken.

Orchestiidæ.

Orchestia littorea Mont. (42). Up to North Hooe, and to Ince Castle.

Calliopiidæ.

Apherusa Jurinii M.Edw. (42). Corner opposite Defiance, right bank.

Ovigerous females, and small half-grown animals (19.8.28).

Gammaridæ.

Gammarus locusta L. (42). Very common up to Morwell Rocks, and to Tredinnick, below Tideford.

Gammarus marinus Leach (42). Common to North Hooe, and to junction of Lynher and Tiddy.

Gammarus duebenii Lilljeb. (42). From about 1 mile below Calstock to Weir Head; from Sheviock Wood to Penimble, below Tideford.

Melita palmata Mont. (42). Up to Weir Quay, usually on hard ground.

Podoceridæ.

Podocerus (Jassa) falcatus Mont. (42). In weed on buoys, up to Neille Point and up to Sheviock Wood. Taken from bottom and in nets. Common.

Podocerus odontonyx G. O. Sars (42). No. 15 Buoy off Bull Point, Hamoaze. Fairly common.

Corophiidæ.

Corophium crassicorne Bruzel (42). Up to $\frac{1}{2}$ mile above Cargreen. Common on buoys and on mussel-bed.

Corophium grossipes L. (42). Common from North Hooe towards Morwellham; R. Lynher from Wacker Creek* to Tideford.

Caprellidæ.

Pseudoprotella phasma Mont. (9). Off lower end of Sheviock Wood, 1 specimen.

Pariambus typicus Kröyer (9). Off lower end of Sheviock Wood, 1 specimen.

\section{Macrura.}

Palæmonidæ.

Leander serratus Pennant (52). Up to Pentillie Quay, and to confluence of Lynher and Tiddy. Common.

- Near Antony, after which the author has named it, passim.-Ed. 
Leander longirostris H.M.-Ed. (52). From St. John's Lake to $\frac{1}{4}$ mile above Calstock Bridge. In Lynher to $\frac{1}{4}$ mile above St. Germans Bridge.

Leander squilla L. (52). Up to Neille Point, and to boathouse near Ince Castle.

Crangonidæ.

Crangon vulgaris L. (52). Up to $\frac{1}{4}$ mile above Calstock, and to $\frac{1}{4}$ mile above St. Germans Bridge. Common.

Anomura.

Paguridæ.

Eupagurus bernhardus L. (5). St. John's Lake ; Bull Point; Hamoaze. Porcellanidæ.

Porcellana longicornis L. (5). Mussel-bed, Neille Point.

BrachyuRA.

Portunidæ.

Carcinus manas Pennant (5). Common up to $\frac{3}{4}$ mile above Calstock Bridge, and to Tredinnick.

INSECTA.

Thysanura.

Petrobius maritimus Leach (39). Up to Port Eliot, and to Warren Point.

Trichoptera.

Leptocerus annulicornis Steph. (40). Larvæ in moss, with brackishwater forms, below Weir Head. A freshwater larva.

Prosobranchiata.

Patellidæ.

Patella vulgata L. (24). Occasional specimens on stones, on mudbank; St. John's Lake, and left bank above Saltash Bridge.

Littorinidæ.

Littorina littorea L. (24). Common up to Neille Point, and to Sheviock Wood.

Littorina obtusata L. (24). Common up to Neille Point, and to Sheviock Wood.

Littorina rudis Maton (24). St. John's Lake; by boathouse near Ince Castle.

Assimineidæ.

Paludestrina stagnalis Baster (24). Common up to North Hooe, and to Sheviock Wood. 
Cypraeidæ.

Trivia europaea Mont. (14). Mussel-bed, Neille Point, 1 specimen.

Pelecypoda.

Mytilidæ.

Mytilus edulis L. (14). Common up to Weir Quay, and to Sheviock Wood.

Scrobiculariidæ.

Scrobicularia plana da Costa (14). Common in stiff mud. Up to Pentillie Quay, and to Port Eliot.

Tellinidæ.

Macoma baltica L. (14). Shore, by boathouse near Ince Castle. Dead shells near Hole's Hole.

Veneridæ.

Tapes pallustra Mont. (14). Rat Island.

Cardiidæ.

Cardium edule L. (14). Common. Up to Hole's Hole, and to St. Germans.

Cycladidæ.

Pisidium casertanum Poli (50). In fine clean sand, down to lower end of Morwell Rocks. Freshwater species among brackish-water forms.

PolyzoA.

Membraniporidæ.

Membranipora Lacroixi Audouin (23). Common. Up to $\frac{1}{2}$ mile above Halton Quay, and to St. Germans Bridge.

Escharidæ.

Lepratia Pallasiana Moll (23). Common. Up to Cargreen, and to Sheviock Wood.

Alcyonidiidæ.

Alcyonidium mytili Dalyell (23). Common. Up to $\frac{1}{2}$ mile above Cargreen, and to shore, by boathouse near Ince Castle.

Vesiculariidæ.

Bowerbankia imbricata Adams (23). Very abundant. Up to $\frac{1}{2}$ mile above Halton Quay, and to confluence of Lynher and Tiddy.

Pedicillinidæ.

Pedicillina cernua Pallas (23). Mussel-bed, Neille Point. 
ECHINODERMATA.

Ophiothricidæ.

Ophiothrix fragilis Abildgaard (2y). Mussel-bed off Neille Point.

Tunicata.

Appendiculariidæ.

Oikipleura dioica Fol. (34). In plankton. Hamoaze up to Impregnable. Molgulidæ.

Molgula manhattensis De Kay (20). St. John's Lake; lower end of Sheviock Wood. Occasional.

Ascidiidæ.

Ascidiella aspersa O.F.M. (21). Common. Up to $\frac{1}{2}$ mile above Hole's Hole, and to Sheviock Wood.

Ciona intestinalis L. (21). Occasional. Shore, by boathouse near Ince Castle.

Botryllidæ.

Botryllus Schlosseri Pallas (20). Up to Hole's Hole on Fucus.

Botrylloides rubrum M.-Ed. (21). Rat Island.

Didemnidæ.

Distalpia sp. Shore, by boathouse near Ince Castle.

Cyclostomata.

Petromyzontidæ.

Petromyzon marinus L. (11). Weir Head.

Pisces.

Salmonidæ.

Salmo salar L. (11). In Tamar and tributaries.

Murænidæ.

Anguilla vulgaris Turton (11). Up to Weir Head.

Syngnathidæ.

Syngnathus acus L. (11). Up to Hole's Hole, and to Sheviock Wood.

Mugilidæ.

Mugil chelo Cuvier (11). Up to Weir Head. Common.

Pleuronectidæ.

Pleuronectes flesus L. (11). Up to Weir Head, and to Port Eliot.

Gobiidæ.

Gobius microps Kröyer (11). Very abundant. Up to Morwell Rocks, and to Port Eliot. 
Agonidæ.

Agonus cataphractus L. (11). Mussel-bed, Neille Point.

Blenniidæ.

Blennius pholis L. (11). Rat Island.

\section{REFERENCES.}

1. Allen. Polychæta of Plymouth. Journ. Mar. Biol. Assoc., X, 1915.

2. Allen and Todd. Fauna of the Exe Estuary. Journ. Mar. Biol. Assoc., VI, 1902.

3. Allen and Todd. Fauna of Salcombe Estuary. Journ. Mar. Biol. Assoc., VI, 1900.

4. Allman. Mon. Gymnobl. Hydroids, 1871.

5. Bell. Hist. Brit. Stalk-eyed Crust., 1853.

6. Bowerbank. Mon. Brit. Spongidæ, iii, 1866.

7. Brady. Mon. Free and Semipar. Copepoda Brit. Is., iii, 1880.

8. Bürger. Das Tierreich, Nemertini, 20, 1904.

9. Chevreux et Fage. Faune de France, Amphipoda, 9, 1925.

10. Darwin. Mon. Cirripedia, Balanidæ, 1854.

11. Day. Brit. Fishes, 2 vols., 1880-4.

12. Fauvel. Faune de France. Polychètes errantes, 5, 1923.

13. Fauvel. Faune de France. Polychètes sédentaires, 16, 1927.

14. Forbes and Hanley. Hist. Brit. Mollusca, i and ii, 1853.

15. Ford. Herring Investigations at Plymouth, iv. Journ. Mar. Biol. Assoc., XV, 1928.

16. Giesbrecht and Schmeil. Das Tierreich. Copepoda, i, 6, 1898.

17. Gosse. Hist. Brit. Sea-anemones, 1860.

18. Gurney. Proc. Zool. Soc., 1924.

19. Grassi. Fauna et Flora Golf. Neapel, Chætognatha, V, 1883.

20. Hartmeyer. Danish Ingolf-Exp., ii, 6, 1923.

21. Herdman. Jour. Linn. Soc., Zool., XXIII.

22. Hincks. Hist. Brit. Hydroid Zooph., 1868.

23. Hincks. Hist. Mar. Polyzoa, 1880.

24. Jeffreys. Brit. Conch., ii, 1863 ; iii, 1865 ; iv, 1867.

25. Joubin. Némertiens, 1894. 
26. Kielhack. Süsswasserfauna Deutschlands, Phyllopoda, 10, 1909.

27. Kenler. Faune de France. i, Echinodermes, 1921.

28. Lebour. Young Gobiidæ of Plymouth. Journ. Mar. Biol. Assoc., XII, 1919.

29. Mayer. Medusæ of the World, 1910.

30. McMurrich. Proc. Zool. Soc., 1921.

31. Michaelsen. Süssw. Deutsch. Oligochæta, 13, 1909.

32. Michaelsen. Das Tierreich. Oligochæta, 10, 1920.

33. Monod. Les Gnathiidæ. Mem. Soc. Sci. Nat. Maroc, XIII, 1926.

34. Nordisches Plankton, 1901-1908.

35. Norman and Stebbing. Trans. Zoo. Soc., XII.

36. Omer-Cooper. Trans. Norfolk and Norwich Nat. Soc., X, 1916-17.

37. Plymouth Marine Fauna. Journ. Mar. Biol. Assoc., VII, 1904.

38. Redeke. Flora en Fauna der Zuiderzee, 1922. Helder.

39. Reilly. Brit. Machilidæ. Ann. Mag. Nat. Hist., 16, 8 ser., XVI, 1915.

40. Rousseau. Larves et Nymphes aquatiques, \&c., 1, 1921, Bruxelles.

41. Russell. A Net for Plankton near Bottom. Journ. Mar. Biol. Assoc., XV, 1928.

42. SARs. Crust. Norway, i, Amphipoda, 1895.

43. Sars. Crust. Norway, ii, Isopoda, 1899.

44. Sars. Crust. Norway, iv, Calanoida, 1903.

45. SARs. Crust. Norway, v, Harpacticoida, 1911.

46. SARs. Crust. Norway, vi, Cyclopoida, 1918.

47. Sars. Crust. Norway, vii, Copepoda. Suppl., 1921.

48. Sars. Crust. Norway, viii, Monstrilloida, \&c., 1921.

49. Spence Bate and Westwood. Brit. Sess.-eyed Crust., ii, 1868.

50. Stelfox. Jour. Conch., 15, 1916-18.

51. Stephenson. A New Brit. Sea-anemone. Journ. Mar. Biol. Assoc., XIII, 1925.

52. Tierwelt der Nord- und Ostsee, X, XII, 1927.

53. Williamson. Recent Foraminifera Gt. Brit., 1858. 